\title{
PERBEDAAN EFEKTIVITS PELARUT ORANGE OIL TERHADAP SEALER BERBASIS RESIS DAN ZINC OXIDE EUGENOL
}

\author{
Eric Alexander Haryotejo ${ }^{1}$, Nalem Rika Rahayu ${ }^{2}$, Dian Soraya Tanjung ${ }^{3}$, Steven Wijaya ${ }^{4}$ \\ Departemen Konservasi Gigi, Fakultas Kedokteran Gigi Universitas Prima Indonesia ${ }^{1234}$ \\ e-mail: diansorayatanjung@yahoo.co.id ${ }^{2}$
}

\begin{abstract}
This study aims to determine the differences in the effectiveness of orange oil solvent against resin-based sealers and zinc oxide eugenol. The samples of this study were resin based sealers and zinc oxide eugenol based sealers which were molded in a cylindrical mold made of aluminum with a diameter of $10 \mathrm{~mm}$ and a height of $3 \mathrm{~mm}$. The total sample size in this study was 60 samples, then divided into 4 groups, 2 groups for resin-based sealers with a time of 2 minutes and 5 minutes, and a sealer based on zinc oxide eugenol with a time of 2 minutes and a time of 5 minutes, after which it was put into incubator with a temperature of $37^{\circ} \mathrm{C}$ for 48 hours, then weighed for each group. Data analysis used paired T test with the Kolmogorov Smirnov normality test. The results showed that the orange oil solvent did not have a significant difference to the resin-based sealers and the zinc oxide eugenolbased sealers. At the immersion time of 2 minutes, the solubility of resin-based sealers and zinc oxide eugenol did not have significant differences ( $p>0.05$ ). Based on the research results, it can be concluded that orange oil solvent is equally effective in both sealers, neither is more effective than the other
\end{abstract}

Keywords: Orange Oil solvent, resin sealer, Zinc Oxide Eugenol sealer.

\begin{abstract}
ABSTRAK
Pelarut berperan melarutkan dan membantu mengeluarkan bahan pengisi saluran akar dengan lebih cepat pada perawatan ulang. Penelitian ini bertujuan untuk mengetahui perbedaan efektivitas pelarut orange oil terhadap sealer berbasis resin dan zinc oxide eugenol. Sampel adalah sealer berbasis resin dan sealer berbasis zinc oxide eugenol yang dicetak dalam sebuah cetakan silindris aluminium dengan diameter $10 \mathrm{~mm}$ dan tinggi $3 \mathrm{~mm}$. Besar sampel sebanyak 60 sampel yang dibagi menjadi 4 kelompok (sealer berbasis resin waktu perendaman 2 menit dan 5 menit, sealer berbasi zinc oxide eugenol waktu perendaman 2 menit dan 5 menit), dilakukan penimbangan sampel sebelum dan sesudah direndam orange oil selama 2 menit dan 5 menit. Analisis data menggunakan uji $\mathrm{T}$ berpasangan dan Uji Normalitas Kolmogorov Smirnov. Hasil penelitian menunjukkan bahwa efektivitas pelarut orange oil terhadap sealer berbasis resin dan zinc oxide eugenol tidak memiliki perbedaan yang signifikan pada waktu perendaman 2 menit dan 5 menit $(\mathrm{p}>0,05)$. Berdasarkan hasil penelitian dapat disimpulkan bahwa efektivitas pelarut orange oil terhadap sealer berbasis resin dan zinc oxide eugenol tidak memiliki perbedaan yang signifikan.
\end{abstract}

Kata kunci: Pelarut orange oil, sealer resin, sealer zinc oxide eugenol. 


\section{INTRODUCTION}

Good endodontic care in general has asuccessrate of up to $94 \%$ [1]. Although it has a high success rate, some cases have problems in the practice and require re-treatment. Inadequate debridement and nonhermetic filling processes are the main causes of root canal treatment failure. Necrotic tissue and remaining bacteria can give rise to periapical inflammation [2].

Generally the treatment option in case of endodontic treatment failure is done by re-treatment of the root canal. All fillers in the root canal system must be removed from the root canal system and $r e$ debrideed [3]. The technique of removing the root channel filler material includes several methods, namely using heat instruments, manual files, rotary, laser technology and the use of solvents. These methods can be used separately or incombination[4].

Martos research proves that the use of solvents shortens the working process and improves cleanliness of the root canal walls. Organic solvents are capable of dissolving the filler material of the root canal. The solvent is used as a main cone softener and sealer so that the filling material can be removed entirely from the root canal.[4]

There are many types of solvents in the field of endodontik including chloroform, eucalyptus oil, etc. Chloroform is the most effective solvent, but it has a carcinogenic effect so its use is prohibited by the U.S.Food and Drug Administration in 1976. Eucalyptus oil is rated less effective for use at room temperature compared to other solvents. Orange oil was originally used to dissolve zinc oxide eugenol sealers. According to [5], orange oil provides a solvent effect similar to xylene but xylene is considered less biocompatible. Then it is recommended to use Orange oil as a replacement. Xylene and orange oil can soften sealer and Gutta percha as well without harmful side effects. Zaccaro's research states that orange oil is the most biocompatible solvent compared to eucalyptus oil, chloroform, xylene and halothane. Zinc oxide eugenol sealer is a commonly used sealer with a high success rate. The loss of the sealer is the silver content that can result in stains on the structure of the teeth, as well as a rapid hardening time in damp and hot places. In addition, resin-based sealer has also been used for many years, for example $\mathrm{AH} 26$ which has the advantage of being resistant to moisture. While $\mathrm{AH}$ Plus has more advantages than $\mathrm{AH} 26$, namely polymerization without producing formaldehyde, more radiopak, shrinkage reduction, thinner and less soluble [6] Mushtaq research shows that xylene has the best solubility in AH Plus sealers, followed by orange oil and tetrachloroethylene. Topcuoglu's research showed that only chloroform had a significant effect in decreasing the attachment strength of all sealers studied compared to the control group, eucalyptus oil and orange oil. Some things that affect the level of solubility sealer such as temperature, vibration, time etc. Research conducted by [7] uses passive ultrasonic activation that uses wave vibrations thus increasing solubility. The results showed that orange oil and eucalyptus oil in four types of sealers including zinc oxide eugenol and resin showed that the highest level of solubility was in zinc oxide eugenol-based sealers and the lowest solubility levels in resin sealers.

\section{METHOD}

The research design used is experimental laboratory with quantitative research design. This research was conducted at the Pharmaceutical Laboratory of Universitas Prima Indonesia. The bound variables in this study were resin sealer and zinc oxide eugenol, and the free variable in this study was orange oil.

The population in this study was resin-based sealers and zinc oxide eugenol-based sealers. The research sample is a resin-based sealer and zinc oxide eugenol-based sealer poured into a cylindrical mold made of aluminum with a diameter of $10 \mathrm{~mm}$ and a height of $3 \mathrm{~mm}$.

The data were analyzed descriptively with the SPSS (Statistical Product and Service Solutions) program, Data analysis using paired $\mathrm{T}$ test with Kolmogorov Smirnov normality test.

\section{RESULT}

\section{Data Analysis Results}

The results of the study were obtained from the calculation of the difference in the results of the first measurement (before soaking the solvent), and the results of the second measurement (after soaking the solvent liquid). The results are written in milligrams (mg). Weighing is done 3 times, then taken the average value and then each divided into 2 subgroups. This study used average values to anticipate errors in the first scale to the third scale. The data of solubility of resin-based sealers and zinc-based oxide eugenol at immersion time of 2 and 5 minutes is shown in table 1

Table 1. Laboratory Research Data

\begin{tabular}{|c|c|c|}
\hline Sealer Type & Average (mg) & $\begin{array}{l}\text { Std. } \\
\text { Devia } \\
\text { tion }\end{array}$ \\
\hline Resin Sealer 2 minutes immersion & 0,5436 & 0,031 \\
\hline Resin Sealer 5 minutes immersion & 0,5572 & 0,034 \\
\hline $\begin{array}{l}\text { Zinc Oxide eugenol Sealer } 2 \\
\text { minutes immersion }\end{array}$ & 0,5410 & 0,020 \\
\hline $\begin{array}{l}\text { Zinc Oxide eugenol Sealer } 5 \\
\text { minutes immersion }\end{array}$ & 0,5413 & 0,015 \\
\hline
\end{tabular}

2. Normality Test

Table 2. Normality Test Results

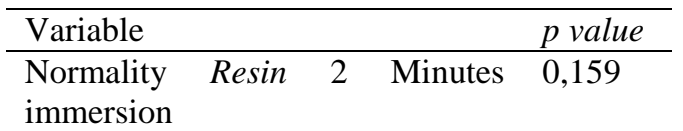




\begin{tabular}{lll} 
Normality Resin 5 & Minutes & 0,831 \\
immersion & & \\
Normality Zinc Oxide eugenol 2 & 0,704 \\
Minutes immersion & 0,625 \\
Normality Zinc Oxide eugenol 5 & \\
Minutes immersion & \\
\hline
\end{tabular}

Table 2. shows normality test results for research data. The average $p$ value is greater than 0.05 or $p>0.05$ which means that the data in this study are entirely normally distributed.

\section{Paired T-Test}

The results of the experiment soaking orange oil solvent against resin-based sealers and zinc oxide eugenol with a soaking time of 2 minutes and 5 minutes based on paired $\mathrm{T}$ Test can be seen in the table below.

Table 3. T Test Results Paired Solubility Sealer Each Treatment Group

\begin{tabular}{lccl}
\hline \multicolumn{2}{l}{ Treatment Group } & & p value \\
\hline $\begin{array}{l}\text { Resin Sealer } \\
\text { immersion }\end{array}$ & minutes & 0,473 \\
Resin Sealer 5 & minutes & 0,000 \\
immersion & & 0,000 \\
Zinc Oxide Eugenol Sealer 2 & 0,000 \\
minutes immersion & \\
Zinc Oxide Eugenol 5 Sealer \\
minutes immersion
\end{tabular}

The data was analyzed using a paired $\mathrm{T}$ test, the value of meaning was determined by $\mathrm{p}$ value $<0.05$. Table 3. shows the significance value of the solubility of each sealer treatment group. Solubility resin-based sealer with a immersion time of 2 minutes has a $p$ value of 0.473 . This suggests that at a 2-minute immersion time, the average solubility of resin-based sealers has no significant difference $(\mathrm{p}>0.05)$. While at the time of immersion 5 minutes has a value of $p$ value of 0.000 . This indicates that at immersion time of 5 minutes, the solubility of resin-based sealers has a significant difference $(\mathrm{p}<0.05)$.

Solubility sealer-based zinc oxide eugenol with a soaking time of 2 minutes has $\mathrm{p}$ value of 0.000 . This states that at a 2-minute immersion time, zinc oxide eugenol-based sealers have significant solubility $(\mathrm{p}<0.05)$. Solubility sealer-based zinc oxide eugenol with a soaking time of 5 minutes has a value of $\mathrm{p}$ value of 0.000. It states that at a 5-minute immersion, zinc oxide eugenol-based sealers have significant solubility.

The differences in solubility of resin-based sealers and zinc oxide eugenol in this study are shown in Figure 1.

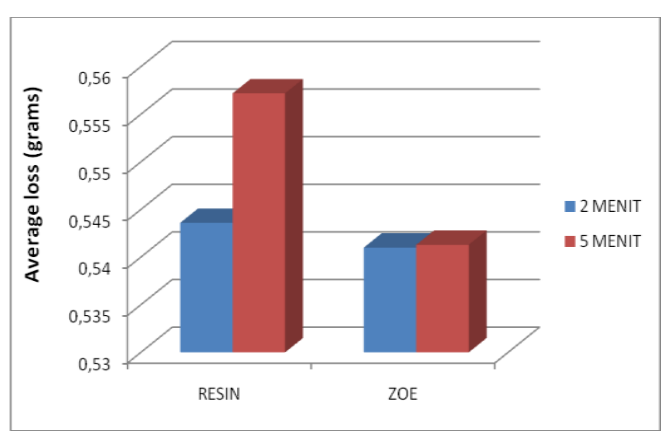

Figure 1. Resin and ZOE Charts After Laboratory Trials With 2 Minutes And 5 Minutes

Table 4. Paired $\mathrm{T}$ Test Results for Sealer Solubility Differences between Treatment Groups

\begin{tabular}{lccl}
\hline \multicolumn{2}{l}{ Treatment Group } & & $p$ value \\
\hline $\begin{array}{l}\text { Resin Sealer } \\
\text { immersion }\end{array}$ & minutes & 0,473 \\
$\begin{array}{l}\text { Resin Sealer } 5 \\
\text { immersion minutes }\end{array}$ & 0,000 \\
Zinc Oxide Eugenol Sealer 2 & 0,000 \\
minutes immersion & \\
$\begin{array}{l}\text { Zinc Oxide Eugenol 5 Sealer } \\
\text { minutes immersion }\end{array}$ & \\
\hline
\end{tabular}

Table 4. shows the meaning value of differences between treatment groups. The solubility of resin-based sealers at immersion times of 2 minutes and 5 minutes has a value of $p$ $=0.71$, this indicates that there is no significant difference $(p>0.05)$ between the solubility of resin-based sealers at 2 and 5 minute immersion times. difference but not significant ( $\mathrm{p}$ value 0.171 $>0.05$ ), solubility of zinc oxide eugenol-based sealer at immersion time of 2 minutes and 5 minutes has a value of $\mathrm{p}=0.968$, this indicates that there is no significant difference $(\mathrm{p}>0.05)$ between solubility of zinc oxide eugenol-based sealer at immersion time of 2 and 5 minutes. For solubility of resin-based sealers and zinc oxide eugenol at immersion time of 2 minutes has a value of $\mathrm{p}=$ 0.763 , this indicates that there is no significant difference $(p>0.05)$ between the solubility of resin-based sealers and zinc oxide eugenol at 2minute immersion time. The solubility of resinbased sealers and zinc oxide eugenol at immersion time of 5 minutes has a value of $\mathrm{p}=0.132$, this indicates that there is no significant difference ( $p>0.05)$ between the solubility of resin-based sealers and zinc oxide eugenol at a 5-minute immersion time.

\section{DISCUSSION}

Endodontic treatments have a high success rate, but the chances of failure of these treatments remain [1]. Failed endodontic treatment should be carried out 
re-treatment of the root canal [3]. All fillers must be removed from the root canal system and re-debrideed. To remove the filler material from the canal a solvent can be used.[3]

Solvents are of important use to facilitate clinicians and save working time during the debridement of root canal fillers. This study was conducted to determine the effectiveness of orange oil as a solvent to remove root canal fillers. The study also tested whether the use of orange oil as a solvent had a difference in effectiveness when tested on resin-based sealers and zinc oxide eugenol-based sealers at immersion times of 2 minutes and 5 minutes.

There are several types of solvents in the field of endodontic including chloroform, eucalyptus oil, xylene and orange oil [6]. The author chose to use orange oil because this solvent has good solublility and has no side effects. Chloroform is considered the most effective solvent but has a carcinogenic effect so its use was banned by the U.S.Food and Drug Administration in 1976, [1]. Eucalyptus oil is considered less effective for use at room temperature than other solvents,[1]. Zaccaro et al. research, 2006 stated that orange oil is the most biocompatible solvent compared to eucalyptus oil, chloroform, xylene and halothane.

Along with the development of the technology and the abundance of root canal fillers, resin materials are not only used in tooth restoration but also used as root canal fillers. Toxic resin sealers provide excellent closing density, are easy to manipulate and harden slowly,[8] Resin-based sealers also have anti-bacterial properties but it can cause large swelling for up to several weeks. Zinc oxide eugenol- based sealer contains zinc oxide. The material is sitoxic, relatively fragile and soluble in tissue fluid. Sealers can cause irritation to periapical tissue when used in high doses, [8]. Each various types of sealers have different hardening times and characteristics. The selection of sealers in this study is based on the popularity of the use of resin-based sealers and zinc oxide eugenol in the community.

The results of this study showed that there was no significant difference between the solubility of resinbased sealers and zinc oxide eugenol-based sealers at immersion time of 2 minutes and 5 minutes. Orange oil solvent effectively dissolves both types of sealers within 2 minutes and 5 minutes.

Based on the results of this study, orange oil solvents are just as effective in both sealers, none of which are more effective than others. zinc oxide eugenol-based sealers are more soluble because they do not have adhesive properties, while resin-based sealers have adhesive properties,[8]. A truly adhesive material will form a strong bond between the core and dentine material so that it can close the existing cavity.

The results of this study are in line with research conducted by Trevisan using passive ultrasonic activation. The results showed that orange oil and eucalyptus oil in four types of sealers including zinc oxide eugenol and resin showed that the highest level of solubility was in zinc oxide eugenol-based sealers and the lowest solubility levels in resin sealers. The results of this study are also similar to mushtaq 2012 research that showed there is a difference in the effectiveness of solubility between zinc oxide eugenolbased sealers and resin-based sealers.

The difference in results with other studies may be due to the study using only 2 minutes and 5 minutes of trial time. A longer immertion time may be required to assess the solubility of the sealer more accurately.

\section{CONCLUSION}

The conclusions of this study are as follows:

. 1. The effectiveness of orange oil solvents in resinbased sealers with a soaking time of 2 minutes and 5 minutes has no significant difference $(\mathrm{p}>0.05)$.

2. effectiveness of orange oil solvents in zinc oxide eugenol-based sealers with a soaking time of 2 minutes and 5 minutes did not have a significant difference $(\mathrm{p}>0.05)$.

3 . The effectiveness of orange oil solvents in resinbased sealers and zinc oxide eugenol with a soaking time of 2 minutes did not have a significant difference $(\mathrm{p}>0.05)$.

4. The effectiveness of orange oil solvents in resinbased sealers and zinc oxide eugenol with a soaking time of 5 minutes did not have a significant difference $(\mathrm{p}>0.05)$.

\section{REFERENCE}

1. Imura, S., Tung, Y.-C., Pan, M.-H., Su, N.-W., Lai, Y.-J., \& Cheng, K.-C. (2007). Black garlic: A critical review of its production, bioactivity, and application. Journal of Food and Drug Analysis, 25(1), 62-70. doi: 10.1016/j.jfda.2016.11.003.

2. Walton E.R. dan Richard E. 1998, Obturasi Saluram Akar, Prinsip dan Praktik Ilmu Endodonsia, Alih Bahasa Narlan S, dkk Edisi Kedua, EGC, Jakarta.

3. Hwang, J; A-H.Chuang; S-J, Sidow; K. Mcnally; JL.Goodin; J-C.Mcpherson. 2015. The Effectiveness of Endodontic Solvents to Remove Endodontic Sealers. Milmed 180: 92-95.

4. Martos, J; M-T, Gastal; L. Sommer; R-G. Lund. 2006. Dissolving efficacy of organic solvents on root canal sealers. Clin Oral Investig 10: 50-4.

5. Harty F.J., 1993, Endodontik Klinis, Alih Bahasa Lilian Yuwono, Edisi 3, Hipokrates, Jakarta.

6. Susin L, Liu Y, Yoon JC, Parente JM, Loushine RJ, Ricucci D, Bryan T, Weller RN, Pashley DH, Tay FR. Canal and isthmus debridement efficacies of two irrigant agitation techniques in a closed system. Int. Endo. J. 2010: 1-14

7. Trevisan, L; I-R.Huerta; C.Michelon; M-D-C.Bello; R. Pillar; C-A-S.Bier. 2017. The Efficacy of Passive Ultrasonic Activation of Organic Solvents on Dissolving Two Root Canal Sealers. IEJ 12: 25 28. 
8. Afiati, R., Rusmiany, A., Karina, R., Sherli, D. 2017. Hubungan Perilaku Ibu Tentang Pemeliharaan Kesehatan Gigi dan Mulut Terhadap Status Karies Gigi Anak : Tinjauan Berdasarkan Pengetahuan, Tingkat Pendidikan, dan Status Sosial di TK ABA 1 Banjarmasin. Banjarmasin : Dentino Jurnal Kedokteran Gigi, 2(1): $56-62$ 